\footnotetext{
JURNAL CEMERLANG: Pengabdian pada Masyarakat

P-ISSN 2654-4741 / E-ISSN 2655-7894

Vol. 4, No. 1, Desember 2021, $109-115$

DOI: https://doi.org/10.31540/jpm.v4i1.1424

PENERBIT: LP4MK STKIP PGRI LUBUKLINGGAU
}

\title{
SOSIALISAI GERAKAN 3M GUNA MEMUTUS PENULARAN COVID-19 DI KELURAHAN TALANG UBI SELATAN PALI
}

\author{
Nita Nurdiana, Fuji Sariutami, Tiara Nicky Cindy Pattinama, \\ Muhammad Bery Mawardy, Rohmad Abdul Kholik \\ Universitas PGRI Palembang, Indonesia \\ Email: nurdiana78@univpgri-palembang.ac.id
}

\begin{abstract}
Slogan Gerakan 3M dicanangkan pemerintah dalam upaya memutus penyebaran Covid19. Kegiatan penyuluhan pelaksanaan gerakan $3 \mathrm{M}$ guna memutus rantai penularan covid-19, menjadi wujud kepedulian civitas akademik Universitas PGRI Palembang dalam membantu pemerintah mensosialisasikan gerakan 3M di masyarakat kelurahan Talang Ubi Selatan, kabupaten PALI. Kegiatan ini bertujuan mengedukasi masyarakat bagaimana cara cuci tangan yang benar serta pentingnya memakai masker. terutama untuk mereka yang berkegiatan di luar rumah. Tidak hanya sekedar melakukan penyuluhan,dalam kegiatan ini juga dilakukan pembagian masker untuk warga sekitar yang beraktifitas d luar rumah. Hasil dari penyuluhan yang dilakukan, masyarakat mulai menyadari berartinya melakukan gerakan 3M. Perihal ini ditunjukkan dengan tersedianya fasilitas cuci tangan di tempat universal salah satunya di TPA Khairussalam. Tidak hanya itu pemahaman warga yang memakai masker dikala berkegiatan di luar rumah mulai bertambah masker dikala berkegiatan di luar rumah. Aktivitas dedikasi pada warga ini meningkatkan pemahaman warga buat patuh serta taat dalam melaksanakan protokol kesehatan dalam upaya memutus penyebaran COVID-19.
\end{abstract}

ABSTRACK

The slogan of the $3 \mathrm{M}$ Movement was launched by the government in an effort to stop the spread of Covid-19. The socialization of the $3 \mathrm{M}$ is concern for the academic community at PGRI Palembang University in helping the government to socialize the $3 \mathrm{M}$, in the community of Talang Ubi Selatan, PALI . This activity aims to educate the public how to wash hands properly and the importance of wearing masks. especially for those who are active outside the home. Not only providing counseling, in this activity the distribution of masks was also carried out for local residents who were active outside the home. As a result of the counseling carried out, the community began to realize the meaning of carrying out the $3 \mathrm{M}$ movement. This is indicated by the availability of hand washing facilities in universal places, one of which is the Khairussalam TPA. Not only that, the understanding of residents who wear masks when doing activities outside the home is starting to increase when they are active outside the home. This dedication activity for residents increases the understanding of residents to be obedient and obedient in implementing health protocols in an effort to stop the spread of COVID-19.

KEYWORDS

Covid-19, Gerakan 3M, Kesadaran Diri

Covid-19, 3M Slogan, Self Awareness
ARTICLE HISTORY

Received 30 Juli 2021

Revised 25 Oktober 2021

Accepted 16 Desember 2021

CORRESPONDENCE Arlina Phelia @ nurdiana78@univpgri-palembang.ac.id 


\section{JURNAL CEMERLANG: Pengabdian pada Masyarakat P-ISSN 2654-4741 / E-ISSN 2655-7894 \\ Vol. 4, No. 1, Desember 2021, 109 - 115 \\ DOI: https://doi.org/10.31540/jpm.v4i1.1424 \\ PENERBIT: LP4MK STKIP PGRI LUBUKLINGGAU}

\section{PENDAHULUAN}

Adanya new emerging infectious disease di China yang disebabkan oleh Coronavirus Disease (Covid-19) mengejutkan dunia di akhir tahun 2019. (Goyena,R.,\&Fallis, 2019). Risiko yang ditimbulkan oleh virus ini termasuk kategori tinggi di tingkat global. Sejak tanggal 30 Januari 2020, WHO sebagai Badan Kesehatan Dunia menetapkan wabah penyakit ini sebagai kedaruratan kesehatan masyarakat yang meresahkan dunia atau Public Health Emergency Of International Concern (PHEIC). (World Health Organization, 2020b). Sejak tanggal 14 Maret 2020, Indonesia menetapkan penyakit Covid-19 sebagai bencana nasional, dimana kasus pertama Covid-19 di Indonesia diumumkan pada tanggal 2 Maret 2020.

Demam, gejala gangguan pernapasan seperti batuk dan sesak napas akan dialami sebagian besar orang yang terinfeksi COVID-19. Lansia dan mereka yang memiliki riwayat masalah kesehatan lainnya seperti penyakit kardiovaskular, diabetes, penyakit pernapasan kronis dan kanker cenderung lebih rentan terinveksi COVID-19 sehingga berkembang menjadi lebih serius. Cara terbaik untuk mencegah dan memperlambat penularan adalah dengan informasi yang baik tentang Covid-19, penyakit yang disebabkan dan bagaimana penyebarannya (World Health Organization, 2020c)

Virus ini, ditularkan melalui kontak langsung dengan percikan droplet dari saluran pernapasan orang yang terinfeksi. Pemerintah Indonesia telah menetapkan langkah-langkah dan upaya pencegahan pandemic covid-19 salah satunya adalah dengan mensosialisasikan gerakan Social Distancing, Melalaui Social Distancing mata rantai penularan dan penyebaran covid-19 dapat dikurangi, yaitu dengan cara menjaga jarak dengan orang lain minimal 1-2 meter, mengurangi kontak langsung dengan orang lain, dan tidak berada di keramaian. (Syapitri1 et al., 2020). Setiap individu dapat membantu pencegahan penyebarannya mendukung langkahlangkah untuk mengendalikan wabah ini ((World Health Organization, 2020a). 


\section{JURNAL CEMERLANG: Pengabdian pada Masyarakat \\ P-ISSN 2654-4741 / E-ISSN 2655-7894 \\ Vol. 4, No. 1, Desember 2021, 109 - 115 \\ DOI: https://doi.org/10.31540/jpm.v4i1.1424 \\ PENERBIT: LP4MK STKIP PGRI LUBUKLINGGAU}

Gerakan 3M (BPKAD, 2020) merupakan suatu gerakan pencanangan penerapan Protokol Kesehatan bagi seluruh masyarakat. Gerakan 3M terdiri atas (1). Memakai masker yang sesuai dengan standar kesehatan WHO atau yang memenuhi SNI. (2). Mencuci Tangan dan menggosok tangan dengan sabun selama 20 - 30 detik, mulai dari telapak tangan hingga sela-sela jari. (3). Menjaga Jarak dengan orang lain minimal 1 meter dimanapun kita berada.

Kelurahan Talang Ubi Selatan merupakan salah satu kelurahan di wilayah Kecamatan Talang Ubi yang terletak $1 \mathrm{~km}$ ke arah Selatan dari kecamatan Talang Ubi. Kelurahan Talang Ubi Selatan mempuyai luas wilayah seluas \pm 2.298 Ha. Kecamatan Talang Ubi terletak di bagian Utara Kabupaten Penukal Abab Lematang Ilir yang mempunyai Luas Wilayah 509,27 $\mathrm{KM}^{2}$. (Wikipedia Bebas, 2020.)

\section{METODE}

Adapun metode yang digunakan dalam kegiatan pengabdian masyarakat ini dapat dilihat pada gambar 1

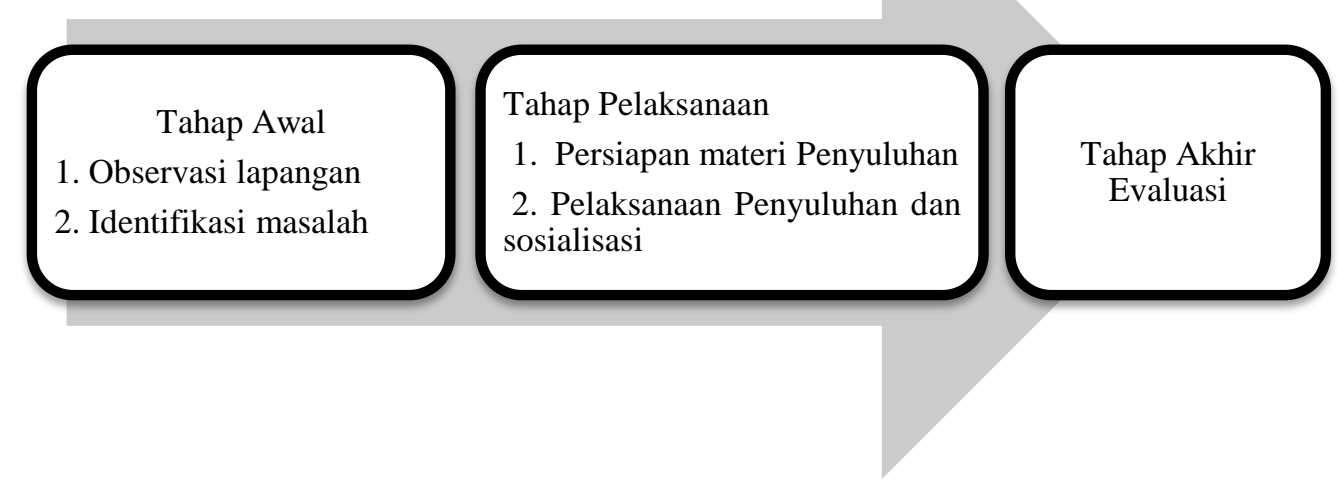

Gambar 1. Metode Pelaksanaan

Dengan tahapan sebagai berikut :

a. Melakukan observasi lapangan bagaimana pelaksanaan protokol kesehatan dalam kehidupan sehari-hari masyarakat Talang Ubi Selatan.

b. Mengidentifikasi permasalahan yang di temukan. 


\section{JURNAL CEMERLANG: Pengabdian pada Masyarakat \\ P-ISSN 2654-4741 / E-ISSN 2655-7894 \\ Vol. 4, No. 1, Desember 2021, 109 - 115 \\ DOI: https://doi.org/10.31540/jpm.v4i1.1424 \\ PENERBIT: LP4MK STKIP PGRI LUBUKLINGGAU}
c. Mempersiapkan materi penyuluhan
d. Memberikan penyuluhan dan sosialisasi kepada warga masyarakat dalam hal ini ketua RT di Talang Ubi Selatan tentang melalui penyuluhan dan sosialisasi gerakan $3 \mathrm{M}$ guna memutus penyebaran Covid-19 di lingkungan masyarakat Talang Ubi Selatan.
e. Melakukan Sosialisasai dan edukasi kepada Masyarakat tentang 3M dalam upaya memutus rantai penyebaran Covid-29 di lingkungan masyarakat Talang Ubi Selatan.

f. Evaluasi

\section{HASIL dan PEMBAHASAN}

Pengabdian pada Masyarakat ini dilaksanakan selama dua hari yaitu pada tanggal 12-13 Desember 2020. Tahap awal pelaksaan kegiatan pengabdian ini berupa observasi lapangan tentang pelaksaan gerakan $3 \mathrm{M}$ di lingkungan masyarakat Talang Ubi Selatan. Berdasarkan hasil observasi lapangan tersebut didapati belum semua masyarakat Talang Ubi Selatan melaksankan gerakan 3M tersebut dalam kegiatan sehari-harinya.

Kegiatan pengabdian ini pelaksanaanya bersamaan dengan Musyawarah Masyarakat Kelurahan (MMK) Talang Ubi Selatan. Tim pengabdian terdiri dari satu orang dosen dibantu oleh 5 orang mahasiswa Universitas PGRI Palembang, kegiatan ini juga di hadiri oleh pihak kelurahan dan UPTD Puskesmas Talang Ubi Selatan serta para ketua RT di lingkungan kelurahan Talang Ubi Selatan pihak kelurahan dan UPTD Puskesmas membahas tentang masalah kesehatan para warga kelurahan Talang Ubi Selatan sedangkan tim pengabdian memberikan penyuluhan tentang mengapa perlu melakukan gerakan $3 \mathrm{M}$ guna memutus penyebaran Covid-19. 

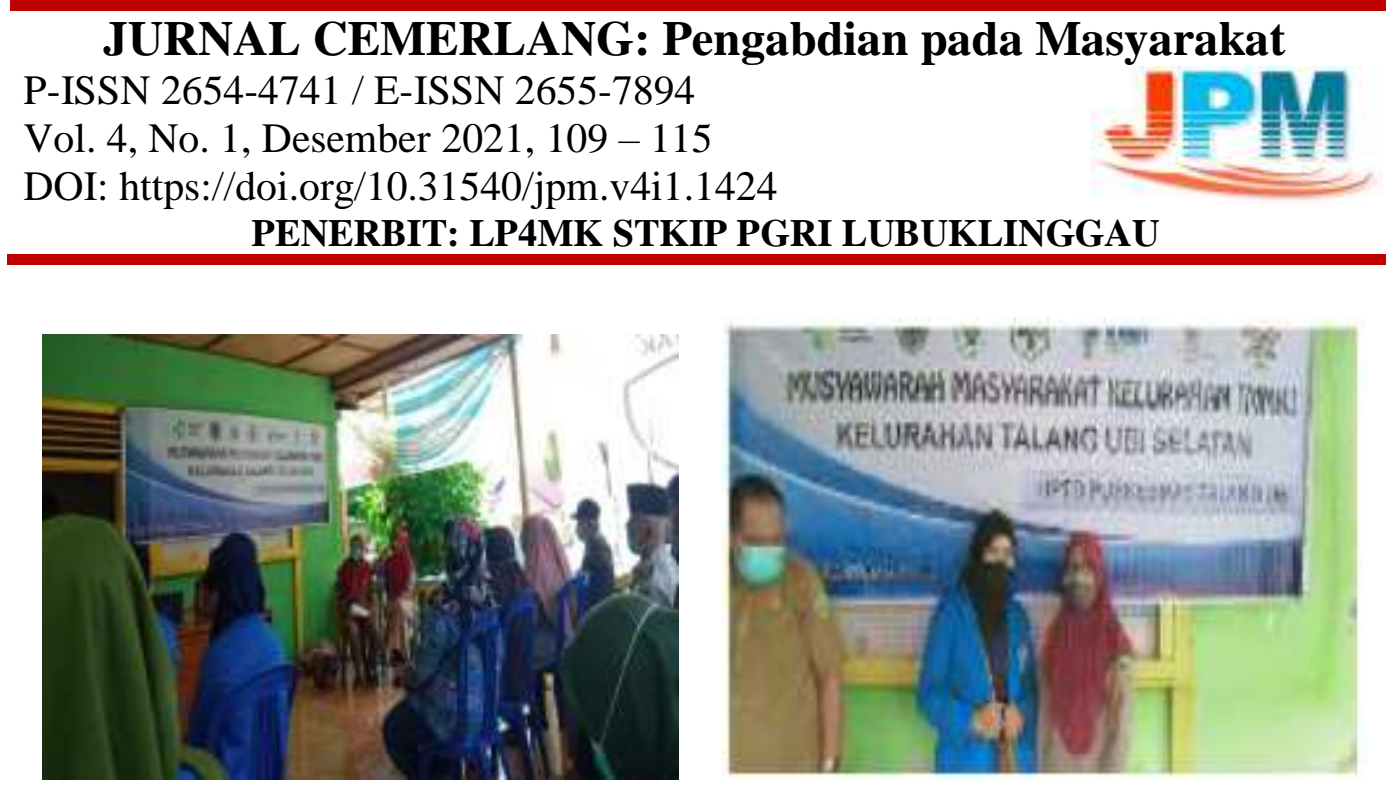

Gambar 2. Penyuluhan bahaya Penularan Covid-19

Melalui kegiatan ini diharapkan para ketua RT dapat memberikan contoh dan dapat memberikan edukasi tentang gerakan 3M kepada warga yang berada di lingkungan RTnya.
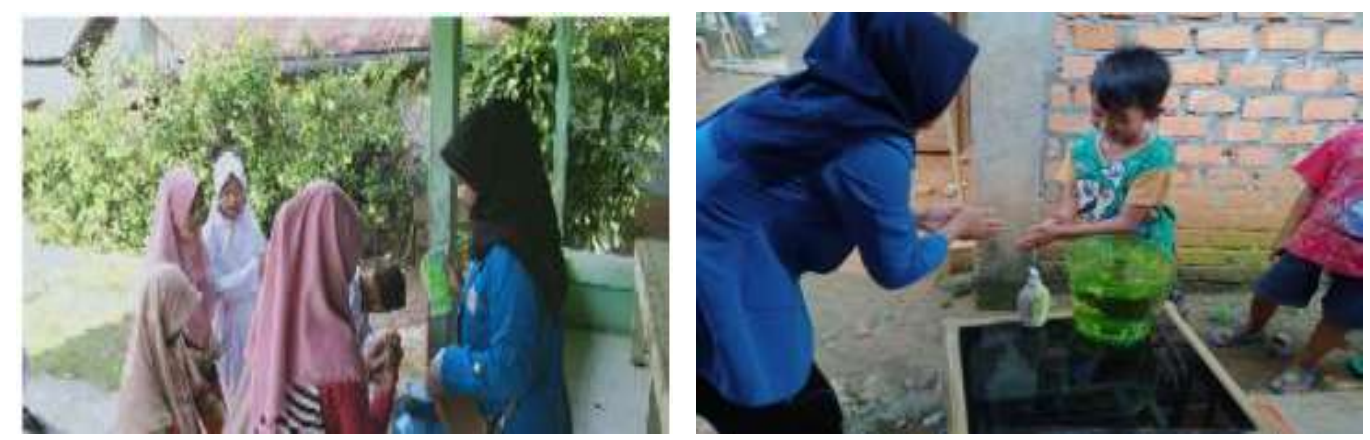

Gambar 3. Menyediakan Sarana dan Edukasi Cara Mencuci Tangan

Setelah selesai melakukan penyuluhan kepada para ketua RT, selanjutnya menemui masyarakat untuk melakukan sosialisasi dan edukasi tentang gerakan 3M kepada masyarakat. Salah satu target keramaian masyarakat adalah warga masyarakat yang mengikuti kegiatan pengajian di TPA Khairussalam, di Jalan Pahlawan RT/RW 001/001. Pada kesempatan ini Tim pengabdian memberikan edukasi tentang bagaimana cara mencuci tangan yang benar, yaitu mencuci tangan dengan air yang mengalir dengan menggunakan sabun selama minimal 20 detik atau dengan cairan pembersih beralkohol. Kegiatan pencucian tangan ini harus sering dilakukan terutama setelah bersin, batuk dan setelah memegang sesuatu. 


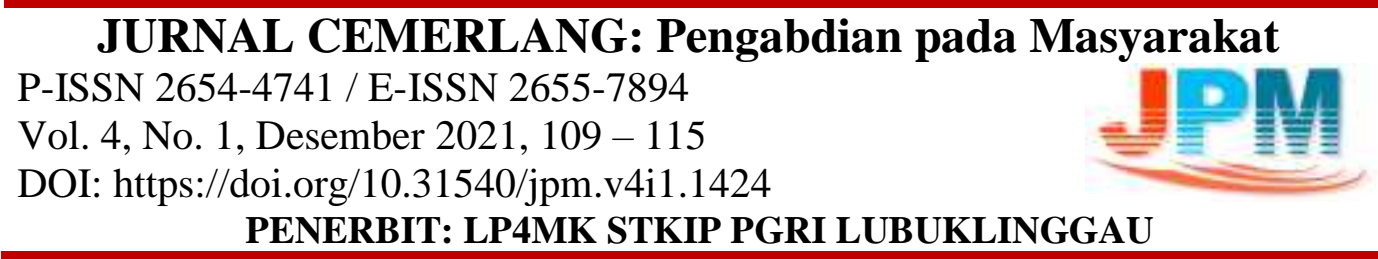

Dengan sering mencuci tangan dapat membantu menyingkirkan dan membunuh virus yang berada di tangan kita.
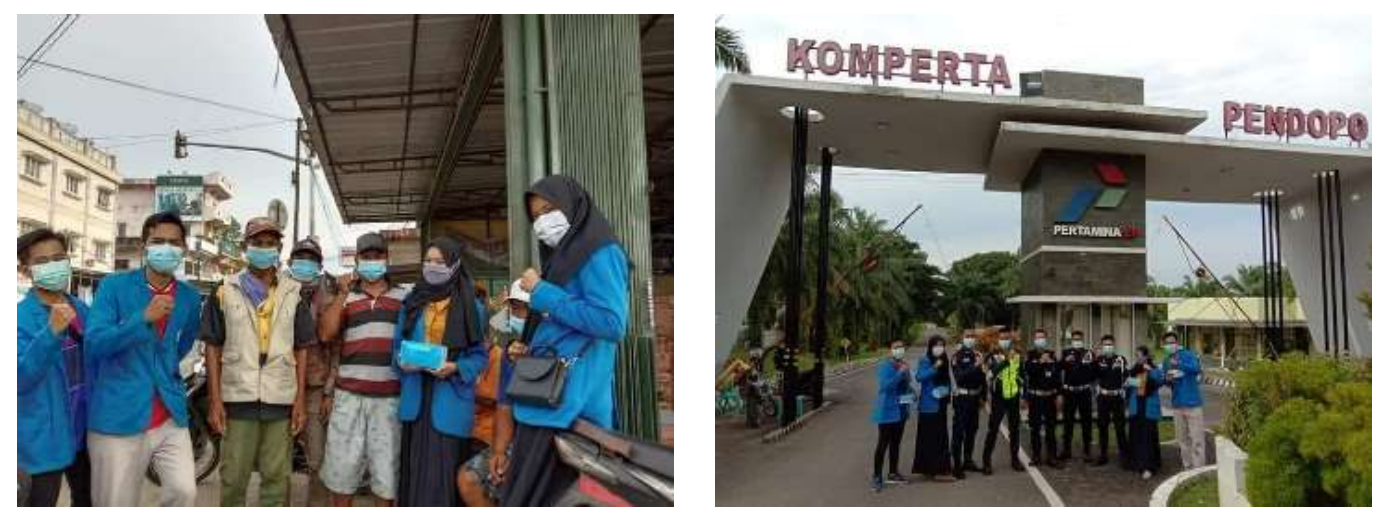

Gambar 4. Pembagian Masker dan Edukasi Memakai Masker

Kegiatan pengabdian masyarakat dilanjutkan dengan memberikan penjelasan kepada masyarakat yang beraktifitas di luar rumah yang di temui Tim Pengabdian di sekitar keluarahan Talang Ubi Selatan. Edukasi yang diberikan tentang kebiasaan memakai masker. Penggunaan masker ini dapat mencegar droplet Kebiasaan ini merupakan langkah kecil yang sangat membantu memutus penyebaran COVID-19. Dengan menggunakan masker berarti masyarakat peduli terhadap diri sendiri dan lingkungan sekitar. dan membagikan masker kepada masyarakat sekitar Kelurahan Talang Ubi Selatan.

Selain itu tim juga memberikan edukasi kepada masyarakat, upaya memutus rantai penyebaran covid-19 juga dapat dilakukan dengan cara menjaga jarak apabila berada dalam suatu keramaian.

\section{SIMPULAN}

Berdasarkan hasil kegiatan Pengabdian yang telah dilakukan di Kelurahan Talang Ubi Selatan dapat diambil kesimpulan

1. Setelah dilaksanakan penyuluhan dan edukasi, masyarakat mulai menyadari pentingnya melaksanakan gerakan 3M. Hal ini ditunjukkan dengan tersedianya sarana mencuci tangan di tempat umum seperti di TPA 


\section{JURNAL CEMERLANG: Pengabdian pada Masyarakat \\ P-ISSN 2654-4741 / E-ISSN 2655-7894 \\ Vol. 4, No. 1, Desember 2021, 109 - 115 \\ DOI: https://doi.org/10.31540/jpm.v4i1.1424 \\ PENERBIT: LP4MK STKIP PGRI LUBUKLINGGAU}

Khairussalam. Selain itu juga kesadaran masyarakat yang menggunakan masker saat beraktifitas d luar rumah mulai meningkat.

2. Kegiatan pengabdian pada masyarakat ini menumbuhkan kesadaran masyarakat untuk patuh dan taat dalam menjalankan protokol kesehatan dalam upaya memutus penyebaran COVID-19.

\section{DAFTAR PUSTAKA}

BPKAD. (2020). GERAKAN 3M DALAM PENCEGAHAN COVID - 19. https://bpkad.jatengprov.go.id/berita2/gerakan-3m-dalam-pencegahan-covid19

Goyena,R.,\&Fallis, A. (2019). Information and Modeling. Journal of Chemical, 53(9), 1689-1699. https://doi.org/10.1017/CBO9781107415324.004

Syapitri1, H., Siregar2, L. M., \& Saragih3, F. L. (2020). Pencegahan Penularan Covid-19 Melalui Sosialisasi Dan Pembagian Masker Di Pasar Pringgan Medan. Jurnal Kreativitas Pengabdian Kepada Masyarakat (Pkm), 3, 422429.

Wikipedia Bebas, E. (n.d.). Kabupaten Penukal Abab Lematang Ilir. https://id.wikipedia.org/w/index.php?title=Kabupaten_Penukal_Abab \%0A_Lematang_Ilir\&oldid=16929971\%0A

World Health Organization. (2020a). Anjuran mengenai penggunaan masker dalam konteks COVID-19. World Health Organization, Juni, 1-17. https://www.who.int/docs/default-source/searo/indonesia/covid19/anjuranmengenai-penggunaan-masker-dalam-konteks-covid-19-june20.pdf?sfvrsn=d1327a85_2

World Health Organization. (2020b). Coronavirus disease (COVID-19) Weekly Epidemiological Update and Weekly Operational Update. https://www.who.int/emergencies/diseases/novel-coronavirus-2019/situationreports

World Health Organization. (2020c). Novel Coronavirus (2019-nCoV) Situation 54. https://www.who.int/docs/defaultsource/coronaviruse/situationreports/20200314-sitrep-54-covid19.pdf?sfvrsn=dcd46351_2.2020) 